\title{
The Validity of the Tourism-induced EKC Hypothesis: The Case of Turkey
}

\author{
Turizm Kaynaklı EKC Hipotezinin Geçerliliği: Türkiye Örnĕgi
}

Emine KILAVUZ

Prof. Dr., Nuh Naci Yazgan University

ekilavuz@nny.edu.tr

https://orcid.org/0000-0001-9639-2368

\section{Burcu ORALHAN}

Assoc. Prof. Dr. Nuh Naci Yazgan University

boralhan@nny.edu.tr

https://orcid.org/0000-0001-8905-0140 5

\section{Sevgi SÜMERLI SARIGÜL}

Asst. Prof. Dr. Kayseri University

ssumerli@kayseri.edu.tr

https://orcid.org/0000-0002-3820-6288

\section{Eyup Emre ULUĞ}

Ph.D. Research Assistant Nuh Naci Yazgan University

eulug@nny.edu.tr

https://orcid.org/0000-0002-3884-065X

\author{
Received \\ : 07.12 .2021 \\ Revised \\ Accepted \\ : 24.12.2021 \\ Type of Article : Research
}

\begin{abstract}
This paper examines the existence of relationship between international tourist arrivals (TA), and Carbon dioxide emissions per capita (CO2) in Turkey over the period 1960-2015. We also use energy use per capita (EU) and GDP per capita (GDP) as a control variables. The autoregressive distributed lag (ARDL) bounds test approach was applied to analyze the long-run relationship among the variables. The results confirmed the validity of the tourism-induced Environmental Kuznets Curve (EKC) hypothesis. An increased tourism demand increases environmental pollution up to a point where the sector attains a certain development level, after which emissions begin to fall. On the other hand, the results indicate that the EKC hypothesis between income and $\mathrm{CO} 2$ emissions has not been confirmed. Energy usage has positive and significant effects on carbon dioxide emissions as expected. For sustainable tourism and to the reduction of emissions in Turkey, environmental protection and the use of renewable energy should be supported by policy makers.
\end{abstract}

Keywords:

Tourism,

EKC hypothesis,

ARDL bounds testing to cointegration

Turkey,

\section{ÖZET}

Anahtar Kelimeler:

Bu makale, 1960-2015 döneminde Türkiye'de uluslararası turist varışları (TA) ile kişi başına düşen Karbondioksit emisyonları (CO2) arasındaki ilişskinin varlığını incelemektedir. Ayrıca, kontrol değişkenleri olarak kişi başına düşen enerji kullanımını (AB) ve kişi başına düşen GSYIH'yı (GSYIH) kullanıyoruz. Değişkenler arasındaki uzun dönemli ilişkiyi analiz etmek için otoregresif dağıtılmış gecikme (ARDL) sınırları

Turizm

ÇKE Hipotezi,

ARDL Sinır Testi, testi yaklaşımı uygulandı. Sonuçlar, turizm kaynaklı Çevresel Kuznets Ĕ̆risi (EKC) hipotezinin geçerliliğini doğruladl. Artan turizm talebi, çevre kirliliğini sektörün belirli bir gelişme düzeyine ulaştı̆̆ noktaya kadar artırmakta ve ardından emisyonlar düşmeye başlamaktadır. Öte yandan, sonuçlar, gelir ve CO2 emisyonları arasındaki EKC hipotezinin doğrulanmadı̆̆ını göstermektedir. Enerji kullanımının karbondioksit emisyonları üzerinde beklendiği gibi olumlu ve önemli etkileri bulunmaktadır. Türkiye'de sürdürülebilir turizm ve emisyonların azaltılması için çevrenin korunması ve yenilenebilir enerji kullanımı politika yapıcılar tarafindan desteklenmelidir. 


\section{INTRODUCTION}

In recent years, we have started to hear more and more about the terms "climate change" and "global warming" which refers to the rise in the average global temperatures by increased concentrations of greenhouse gases (GHG) in the atmosphere. They are among the most important problems because of the increase in the concentration of GHG, which has significant negative effects on humans and the environment worldwide. There are a lot of factors such as economic growth, gross capital formation, trade openness, urbanization, agriculture, energy use, tourism, etc. which lead to an increase in GHG emissions. The countries that heavily dependent on their natural resources and environment are affected much more negatively by global warming. It is necessary to take quick measures in all areas which include agriculture, forestry, energy, infrastructure, tourism, energy-intensive manufacturing industries, etc. Otherwise, global warming will increase hunger and water crises, health problems, low employment and growth, loss of biodiversity, spreads of pests and pathogens, etc. Tourism is a sector that provides significant income, employment, and foreign exchange for many countries. But on the other hand, it also causes pollution because of waste, energy use, and transportation. As the tourism industry is a rapidly growing industry and has a high level of relationship with other industries, it causes large amounts of carbon dioxide (CO2) emissions and negative influence on climate change and the ecological environment.

The relationship between the international tourism sector, energy consumption and, greenhouse gases attracts the attention of many researchers in recent years (Chishti et al., 2020; Koçak et al., 2020; Balsalobre-Lorente et al., 2020; Ben Jebli, et al., 2019; Tang et al., 2018; Azam et al., 2018; Doğan and Aslan, 2017; Shakouri et al., 2017; Ben Jebli et al., 2015; Katircioğlu, 2014a; Katircioğlu, 2014b; Lee and Brahmasrene, 2013; Tiwari et al., 2013). Depending on the purpose, energy usage in the tourism sector can be divided into two groups as transportation and destination (accommodation, food, and beverage, touristic activities, etc.). For this reason, the relationship and estimates of energy consumption and GHG emissions in the tourism sector are very important in terms of policy recommendations (Wu and Shi, 2011). Becken and Simmons (2002) report that tourist attractions and activities increase energy demand which causes environmental pollutions.

There has been an increasing trend in global GHG emissions since the beginning of the 21st century. CO2 emissions are is the most important greenhouse gases generated from human activities and the main responsible for global warming (EPA, 2019). One of the GHG is CO2 which is the largest contributor to climate change and comes heavily from the combustion of fossil fuels. GHG emissions have been increasing since the first industrial revolution which led to significant increases in energy use and output. A serious decline in carbon emissions is required to keep the world at a livable temperature. In 2019, China (30.34\%), the United States (13.43\%), India (6.83\%), the EU27+UK (8.69\%), Russia (4.71\%), and Japan (3.03\%)- the world's largest CO2 emitters- together accounted for $67 \%$ of total global fossil CO2. China and the US, are responsible for more than $40 \%$ of the global emissions. Turkey is responsible for 1.09\% of the global emissions in 2019 (Crippa et al., 2020; WEFORUM, 2019). The statistics show that the level of carbon dioxide emissions increased during the last years in Turkey and rose from 205.7 million metric tons in 2000 to 383.3 million metric tons in 2019 (Statista, 2020). Turkey's high economic and population growth strongly increases the energy demand. In 2018, Turkey's primary energy supply consists of petroleum $29.2 \%$, natural gas $28.6 \%$, hard coal $17.4 \%$ lignite $10.5 \%$ and geothermal $5.8 \%$ which the share of fossil resources is $86.3 \%$. They have negative effects on air and environmental pollution (MMO, 2020).

The energy sources for doing work are called nonrenewable and renewable. In many countries, most energy sources are nonrenewable such as fossil fuels (coal, natural gas and petroleum), hydrocarbon gas liquids and nuclear energy. Increasing consumption of fossil fuels in the world depending on industrialization, increase of the world population and the quality of life cause environmental pollution, which causes an increase in health risks and global climate change problem (Panwar et al., 2011). Energy requirements are largely met by transforming fossil fuels into various forms of energy but different GHG emissions are released into the atmosphere during this transformation process (Kelly \& Williams, 2007).

International tourism is one of the largest and fastest-growing sectors in the world and now represents $10 \%$ of global employment and 10\% of global GDP (World Tourism Organization (UNWTO) and International Transport Forum (ITF), 2019). The technical report in 2008, prepared by an expert team of the United Nations, is the first detailed initiative to determine the global share of tourism-induced $\mathrm{CO} 2$ emissions (UNWTO et al., 2008). According to the report, tourism makes a significant contribution to climate change and emissions are expected to increase significantly in the future. It was estimated that between $3.7 \%$ and $5.4 \%$ of global $\mathrm{CO} 2$ emissions in 2005 originated from the tourism-related sectors (transport, accommodations and activities) and the transportation sector causes around $75 \%$ of the CO2 emissions generated by tourism (UNWTO et al., 2008). Transport-related 
$\mathrm{CO} 2$ Emissions of the Tourism Sector Report has been prepared to update the estimate of the largest component of tourism GHG emissions which are transport-related emissions by UNWTO and the International Transport Forum (ITF) in 2019. The estimation results for 2030 show that the total expected transport-related tourism emissions (excluding cruise) is 1.998 million tonnes of $\mathrm{CO} 2$ which would represent $23 \%$ of the total expected transport emissions (UNWTO and ITF, December 2019). Gössling (2013) analyzed national emissions from tourism and indicate that emissions from tourism are equivalent to $5-15 \%$ of official national emissions and growing rapidly.

The COVID-19 pandemic shows that the world tourism industry is experiencing a negative trend due to the decline in tourism demand. For this reason, countries that are dependent on tourism in terms of foreign exchange earnings and employment have been adversely affected by the COVID-19 pandemic period. Under the international tourism 2020 scenarios (UNWTO, 7 May 2020), international tourism is expected to decrease by $60-80 \%$. This means 850 million to 1.2 billion international tourists and 100 to 120 million tourism jobs lost. Therefore, it is estimated that tourism revenues will decrease by US $\$ 910$ billion to US $\$ 1.2$ trillion in 2020. Therefore, COVID19 is not only causing a health-related crisis, but also an economic crisis. However, the decreasing demand in the tourism sector causes a decrease in $\mathrm{CO} 2$ emissions in the world. Global greenhouse gas emissions fell suddenly roughly 10 to 30 per cent on average during April 2020 because of COVID-19-related restrictions (Forster et al., 2020). Liu et al. (2020) stated that in the first half of 2020, there was a sudden drop in global CO2 emissions of $8.8 \%$ compared to the same period of 2019. According to Gössling et al. (2020), the main causes of increased $\mathrm{CO} 2$ emissions and pandemic threats in the 21st century are similar. Factors such as increasing population, urbanization, industrialization, increase in production, transportation and increased mobility in the world are effective in the spread of pathogens.

Especially after the industrial revolutions, the dependence of production on energy and the predominance of fossil fuels in energy production cause environmental pollution. For this reason, there are studies and models investigating the relationship between production and environmental pollution. The environmental Kuznets curve (EKC) hypothesis (Grossman and Krueger, 1991; Grossman and Krueger, 1995) claims that while an increase in income at low-income levels has harmful effects on the environment after the income level reaches a certain level, the negative effect of the increase in income on the environment begins to decrease. This is because as the country develops and new technologies are found, environmentally friendly production begins. The hypothesis is called the inverted U-shaped hypothesis. Similar to the EKC hypothesis, it is expected an inverted U-shaped type relationship between tourism arrival and environmental degradation is called the tourism-induced EKC hypothesis. Because tourism demand is highly sensitive to environmental quality. An increased tourism demand increases environmental pollution up to a point where the sector attains a certain development level, after which emissions begin to fall.

Within the framework of the variables mentioned above, we analyze the long-term relationship among $\mathrm{CO} 2$ emissions, the number of tourists' arrivals, economic growth, and energy usage for Turkey. We also investigate the question which whether or not does the tourism sector increase environmental pollution? The rest of the paper is organized as follows. The second section is a literature review explaining the relationship between tourism and environmental pollution with other explanatory variables. The third section reports the empirical results and their discussions. A summary of the analysis results and some suggestions for further research are presented in section four.

\section{LITERATUR REVIEW}

Academic studies on global warming and environmental pollution have been increasing in recent years. The impact of the tourism sector on global warming is one of the research topics (Chishti et al., 2020; Koçak et al., 202; Balsalobre-Lorente et al., 2020; Ben Jebli, et al., 2019; Tang et al., 2018; Azam et al., 2018; Fang et al. 2018; Doğan and Aslan, 2017; Shakouri et al., 2017; Pandy, 2017; Hoogendoorn and Fitchett, 2016; Ben Jebli et al., 2015; Katircioğlu, 2014a and 2014b; Lee and Brahmasrene, 2013; Tiwari et al 2013; Scott and Lemieux, 2010; Dwyer et al., 2009). Using different methods, they analyzed whether the tourism sector has an impact on GHG emissions. Lenzen et al. (2018) find that tourism's global carbon footprint has increased from 3.9 to $4.5 \mathrm{GtCO} \mathrm{e}$ between 2009 and 2013 using 160 countries data. They also state that the rapidly growing tourism sector will constitute an increasing part of the world GHG emissions due to its high carbon intensity in the future. Since the tourism industry is the most diverse business sector, It is not easy to determine tourism-related energy consumption. The results of the research on tourism and $\mathrm{CO} 2$ emissions are inconclusive. Some studies have concluded that transport is the main driver of GHG emissions (Unger et al., 2016; Nepal, 2008; UNWTO, UNEP, 
WMO, 2008; Sarrano-Bernardo et al., 2012). Liu et al. (2011) suggest that the input-output analysis could be used in computing $\mathrm{CO} 2$ emission from energy consumption for different sectors related to the tourism industry. They also emphasize the important contribution of the transportation sector to carbon emissions. Solarin (2013), Katircioğlu et al. (2014), Hoyer (2000) and Saenz-de-Miera \& Rossello (2014) found a positive relationship between tourist arrivals and emissions. On the other hand, some studies (Scott 2011; Weaver 2011; Lee and Brahmasrene 2013) indicate that sustainable tourism could cause a decrease in CO2 emissions. That is why the relationship between tourism development and $\mathrm{CO} 2$ emissions is not always positive. Balsalobre-Lorente et al. (2020), Shakouri et al. (2017), Sherafatian-Jahromi et al. (2017) and Paramati et al. (2016) found the tourisminduces EKC hypothesis between tourism and environmental pollutions. The tourism sector is a highly climatesensitive economical sector and has affected by weather and climate variations. Thus, there may be a bilateral relationship between the tourism sector and climate changes. This result is very important and will cause problems like unemployment, inequality, poverty and migration in the future for the global economy. Some studies analyzing the relationship between $\mathrm{CO} 2$ emissions and tourism are briefly summarized in Table 1 below.

Table 1. Summary of the Studies that Examined the Tourism-CO2 Relationship

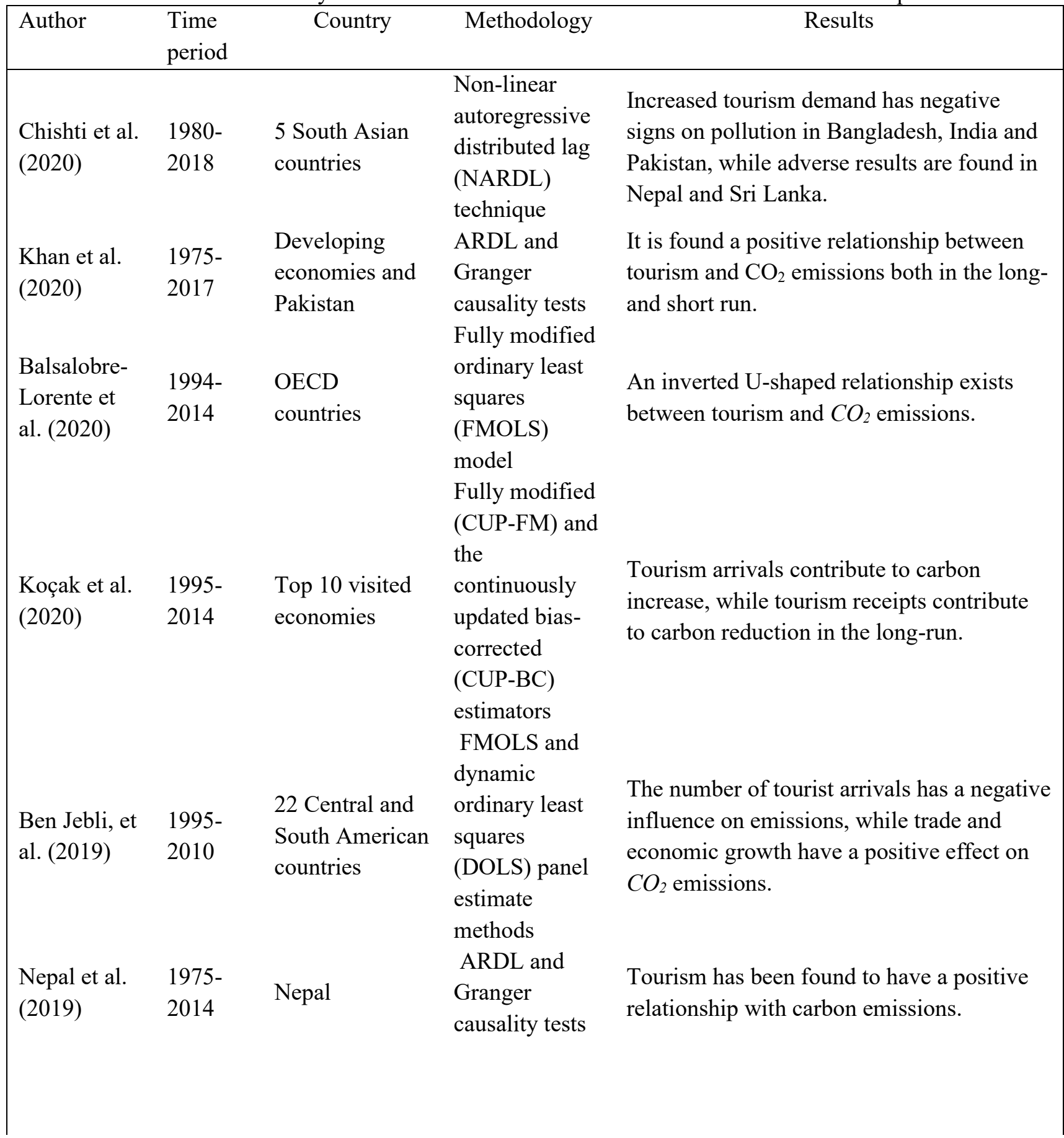




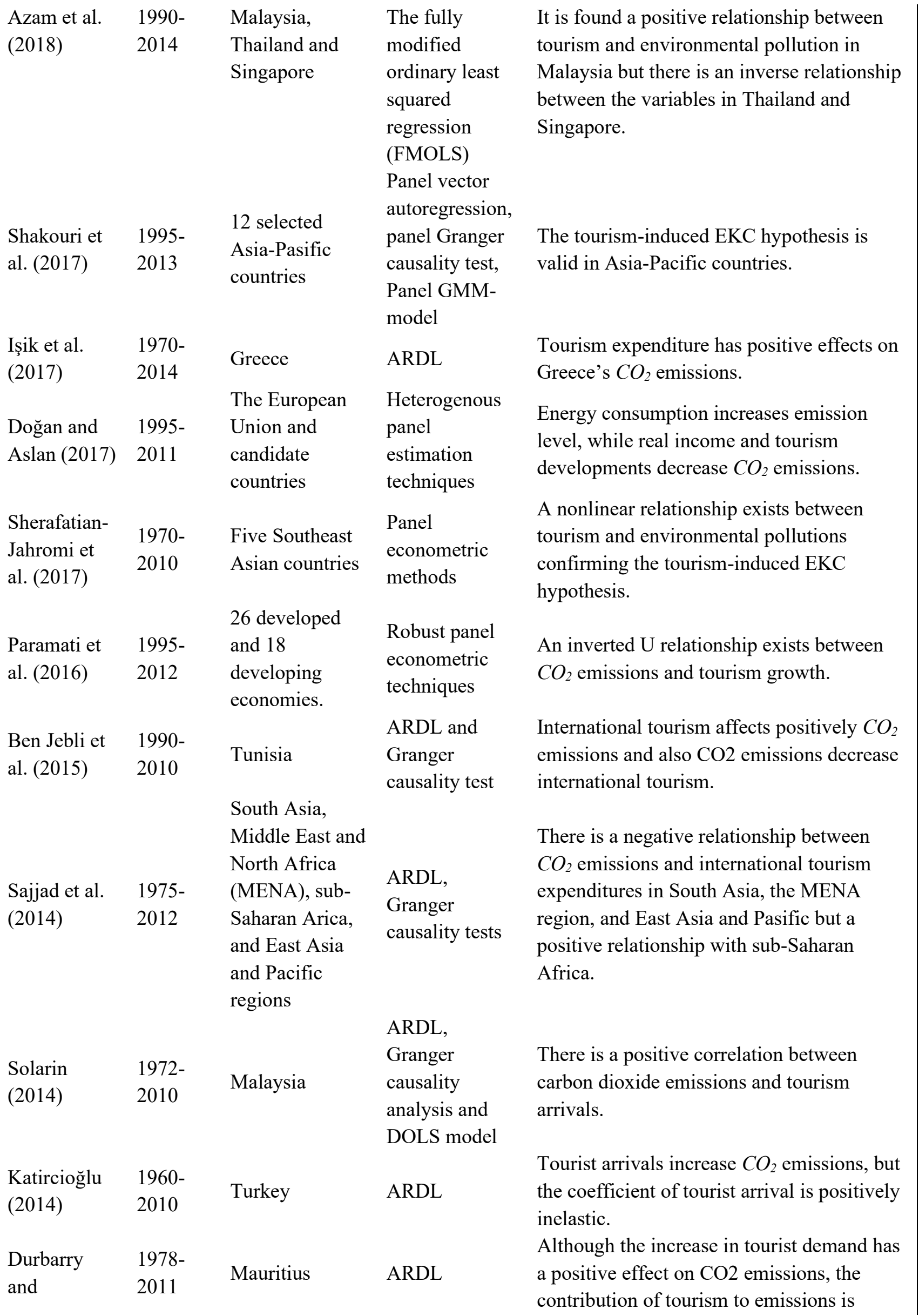




\begin{tabular}{|c|c|c|c|c|}
\hline $\begin{array}{l}\text { Seetanah } \\
(2015)\end{array}$ & & & & $\begin{array}{l}\text { relatively small compared to other } \\
\text { explanatory variables. }\end{array}$ \\
\hline $\begin{array}{l}\text { Katircioğlu } \\
\text { et al. (2014) }\end{array}$ & $\begin{array}{l}1970- \\
2009\end{array}$ & Cyprus & $\begin{array}{l}\text { ARDL, } \\
\text { Granger } \\
\text { causality tests. }\end{array}$ & $\begin{array}{l}\text { Increased tourism demand leads to } \mathrm{CO}_{2} \\
\text { emissions. }\end{array}$ \\
\hline $\begin{array}{l}\text { Katircioğlu } \\
(2014 b)\end{array}$ & $\begin{array}{l}1971- \\
2010\end{array}$ & Singapore & DOLS model & $\begin{array}{l}\text { It is found a U-shaped relationship between } \\
\text { tourism and pollution confirming the } \\
\text { tourism-induced EKC hypothesis. }\end{array}$ \\
\hline $\begin{array}{l}\text { Lee and } \\
\text { Brahmasrene } \\
(2013)\end{array}$ & $\begin{array}{l}1988- \\
2009\end{array}$ & $\begin{array}{l}\text { European Union } \\
\text { countries }\end{array}$ & $\begin{array}{l}\text { Panel } \\
\text { cointegration } \\
\text { and fixed } \\
\text { effects models } \\
\text { Panel-data }\end{array}$ & $\begin{array}{l}\text { Economic growth has a positive effect while } \\
\text { tourism and FDI have a negative influence } \\
\text { on } \mathrm{CO}_{2} \text { emissions. }\end{array}$ \\
\hline $\begin{array}{l}\text { Tiwari et al. } \\
\text { (2013) }\end{array}$ & $\begin{array}{l}1995- \\
2005\end{array}$ & $\begin{array}{l}25 \text { OECD } \\
\text { countries }\end{array}$ & $\begin{array}{l}\text { Vector } \\
\text { Autoregression } \\
\text { (PVAR) }\end{array}$ & Tourism has insignificant impact on $\mathrm{CO}_{2}$. \\
\hline
\end{tabular}

\section{GENERATION OF THE DATA}

\subsection{Theoretical Model}

As we mentioned above, there are different determinants of environmental pollution such as GDP, energy and electricity consumptions, tourism, trade openness, urbanization, financial development, agriculture. This study mainly examines the possible influence of tourism arrival (TA) on air pollution in Turkey which is the main tourism destination of the world. The dependent variable is $\mathrm{CO} 2$ emission which accounts for over $50 \%$ of green gas emissions and is an indicator of air pollution. We used GDP and square of GDP as an independent variable to test the existence of the Environmental Kuznets Curve (EKC) hypothesis, which investigates the relationship between real income growth and environmental pollution. WE used also TA and square of TA to test tourism induced EKC hypothesis, which determines the relationship between tourist arrivals and environmental pollution. The other independent variable is energy consumption (EU). Tourism is an energy-dependent sector and is an important determinant of income in Turkey. Therefore, we included GDP, tourism arrivals and energy use as independent variables in the model to determine the effects of these variables on $\mathrm{CO} 2$ emissions. The model is specified as follows:

$$
C O 2_{t}=f\left(G D P_{t}, G D P_{t}^{2} T A_{t}, T A_{t}^{2}, E U_{t}\right)
$$

We used the model which is the log-linear form and written as follows:

$$
\ln C O 2_{t}=\beta_{0}+\beta_{1} \ln G D P_{t}+\beta_{2} \ln G D P_{t}^{2}+\beta_{3} \ln T A_{t},+\beta_{4} \ln T A_{t}^{2}+B_{5} \ln E U_{t}+\mu_{t}
$$

All data used in this study are annual and collected from the World Bank's (WB) World Development Indicators (WDI) database between 1960 and 2015, according to data availability. Table 2 indicates the variables as well as their definitions and sources of data. All variables are in natural logarithmic forms.

Table 2. Variables and definitions (1960-2015)

\begin{tabular}{ll}
\hline Symbol & Definition and units of measurement \\
\hline $\mathrm{CO}_{2}$ & $\begin{array}{l}\text { Carbon dioxide emissions measured as metric tons } \\
\text { per capita }\end{array}$ \\
$\mathrm{GDP}$ & GDP per capita (constant 2010 US\$) \\
$\mathrm{GDP}^{2}$ & The squared term of GDP \\
$\mathrm{TA}$ & International tourism, number of arrivals
\end{tabular}


$\mathrm{TA}^{2} \quad$ The squared term of TA

EU Energy use ( $\mathrm{kg}$ of oil equivalent per capita)

The hypotheses of this paper are as follows.

Hypothesis 1: According to the Environmental Kuznets Curve (EKC) approach, it is expected that the $\beta 1$ parameter will be positive and the $\beta 2$ parameter will be negative $(\beta 1>0, \beta 2<0)$.

Hypothesis 2: According to an inverted $\mathrm{U}$-shaped relationship between TA and $\mathrm{CO} 2$, the $\beta 3$ parameter is expected to be positive and the $\beta 4$ parameter to be negative $(\beta 3>0, \beta 4<0)$.

Hypothesis 3: Increasing energy usage increases $\mathrm{CO} 2$ emissions $(\beta 5>0)$.

\section{RESULTS}

\subsection{Unit Root Test}

In the first stage of the analysis, Phillips-Perron (PP) and DF-GLS unit root tests were applied to investigate the stationarity level of the variables. The DF-GLS test stands out due to its strong performance in small samples (Elliot et al., 1996). The results of the unit root test which are applied intercept and intercept and trend form of PP are presented in Table 3. GDP, GDP2, TA and TA2 variables have unit roots in their level forms at a 5 per cent significance level and they are integrated after the first differences. On the other hand, we can reject the null of unit root for $\mathrm{CO} 2$ variable which is found to be stationary in level.

Table 3. Phillips-Perron unit root analysis

\begin{tabular}{|c|c|c|c|c|}
\hline \multirow[b]{2}{*}{ Variable } & \multicolumn{2}{|r|}{ Level } & \multicolumn{2}{|r|}{ 1st Difference } \\
\hline & Constant & Constant\&Linear Trend & Constant & Constant\&Linear Trend \\
\hline $\operatorname{lnCO} 2$ & $\begin{array}{l}-3.6605^{*} \\
(0.0075)\end{array}$ & $\begin{array}{l}-3.0081 \\
(0.1394)\end{array}$ & - & - \\
\hline $\ln E U$ & $\begin{array}{l}-1.1352 \\
(0.6956)\end{array}$ & $\begin{array}{l}-2.5675 \\
(0.2962)\end{array}$ & $\begin{array}{c}-7.2167^{*} \\
(0.0000)\end{array}$ & $\begin{array}{l}-7.2961^{*} \\
(0.0000)\end{array}$ \\
\hline $\operatorname{lnGDP}$ & $\begin{array}{c}0.3067 \\
(0.9766)\end{array}$ & $\begin{array}{l}-2.3060 \\
(0.4236)\end{array}$ & $\begin{array}{l}-7.2704 * \\
(0.0000)\end{array}$ & $\begin{array}{l}-7.2178^{*} \\
(0.0000)\end{array}$ \\
\hline $\mathrm{LnGDP}^{2}$ & $\begin{array}{c}0.5898 \\
(0.9882)\end{array}$ & $\begin{array}{l}-1.9903 \\
(0.5935)\end{array}$ & $\begin{array}{l}-7.2003^{*} \\
(0.0000)\end{array}$ & $\begin{array}{l}-7.1862^{*} \\
(0.0000)\end{array}$ \\
\hline $\operatorname{lnTA}$ & $\begin{array}{l}-1.6231 \\
(0.4642)\end{array}$ & $\begin{array}{l}-2.5727 \\
(0.2939)\end{array}$ & $\begin{array}{c}-7.8343^{*} \\
(0.0000)\end{array}$ & $\begin{array}{c}-7.9982 * \\
(0.0000)\end{array}$ \\
\hline $\operatorname{lnTA}{ }^{2}$ & $\begin{array}{l}-0.9539 \\
(0.7633)\end{array}$ & $\begin{array}{l}-2.5185 \\
(0.3184)\end{array}$ & $\begin{array}{l}-8.1397^{*} \\
(0.0000)\end{array}$ & $\begin{array}{c}-8.1342 \\
(0.0000)\end{array}$ \\
\hline
\end{tabular}

DF-GLS unit root test results are given in Table 4. GDP, GDP2 and TA2 variables are significant at the levels. Thus, the null hypothesis which variables contain a unit root are rejected. $\mathrm{CO} 2$, TA, and EU variables are stationary at the first difference.

Table 4. DF-GLS Unit Root Test

\begin{tabular}{|c|c|c|c|c|}
\hline \multirow[b]{2}{*}{ Variable } & \multicolumn{2}{|l|}{ Level } & \multicolumn{2}{|l|}{ 1st Difference } \\
\hline & Constant $^{\mathrm{a}}$ & $\begin{array}{c}\text { Constant\&Linear } \\
\text { Trend }^{\text {b }}\end{array}$ & Constant $^{\mathrm{a}}$ & Constant\&Linear Trend ${ }^{\mathrm{b}}$ \\
\hline $\ln \mathrm{CO} 2$ & 1.5204 & -1.4276 & $-7.9811^{*}$ & $-7.1508^{*}$ \\
\hline $\operatorname{lnEU}$ & 1.8655 & -2.5671 & $-6.2942 *$ & $-6.7649 *$ \\
\hline $\operatorname{lnGDP}$ & $2.7460 *$ & -2.3278 & - & - \\
\hline LnGDP $^{2}$ & $2.8847 *$ & -2.0867 & - & - \\
\hline
\end{tabular}




\begin{tabular}{|c|c|c|c|c|}
\hline $\operatorname{lnTA}$ & 1.7933 & -1.9571 & $-7.7341^{*}$ & $-8.0457 *$ \\
\hline $\operatorname{lnTA} T^{2}$ & $2.0625 *$ & -2.2465 & - & - \\
\hline
\end{tabular}

\subsection{ARDL Bound Test}

Because we have a group of time-series, some I(0), others I(1), we employed the ARDL bound test to ensure the validity of long-run relationships among variables (Pesaran and Shin, 1998; Pesaran et al., 2001). In a classical cointegration test (Engle and Granger (1987), Phillips and Hansed (1990) and Johansen (1988)) all variables must be equally stationary. However, the ARDL model can be used if the variables are stationary to different degrees (except I (2)). ARDL model contains the lagged value(s) of the dependent variable, current and lagged values of regressors as explanatory variables. ARDL limit test developed by Pesaran et al. (2001) reveals long-term relationships between variables regardless of whether the series is I (0) or I (1). If variables are cointegrated after the boundary test, both short-run (ARDL) and long-run (VECM) models are used. The basic ARDL (p, q1, q2, $\mathrm{q} 3, \mathrm{q} 4, \mathrm{q} 5$ ) model used in the study around this advantage provided by the method can be expressed as follows:

$$
\begin{aligned}
& \operatorname{lnCO2} 2_{\mathrm{t}}=\alpha+\sum_{i=1}^{p} \beta_{1 i}(\operatorname{lnCO2})_{t-i}+\sum_{i=0}^{q 1} \beta_{2 i}\left(\ln G D P_{t-i}\right)+\sum_{i=0}^{q 2} \beta_{3 i}\left(\ln G D P_{t-i}^{2}\right)+ \\
& \sum_{i=0}^{q 3} \beta_{4 i}\left(\ln T A_{t-i}\right)+\sum_{i=0}^{q 4} \beta_{5 i}\left(\ln T A_{t-i}^{2}\right)+\sum_{i=0}^{q 5} \beta_{6 i}(\ln E U)_{t-i}+\varepsilon_{t}
\end{aligned}
$$

ARDL boundary test model adapted to work for cointegration;

$$
\begin{aligned}
& \Delta \operatorname{lnCO2} 2_{t}=\alpha+\delta_{1} \operatorname{lnCO} 2_{t-1}+\delta_{2} \ln G D P_{t-1}+\delta_{3} \ln G D P_{t-1}^{2}+\delta_{4} \ln T A_{\mathrm{t}-1}+ \\
& \delta_{5} \ln T A_{t-1}^{2}++\delta_{6} \ln E U_{t-1}+\sum_{i=1}^{p} \beta_{1 i} \Delta(\ln C O 2)_{t-i}+\sum_{i=0}^{q 1} \beta_{2 i} \Delta(\ln G D P)_{t-i}+ \\
& \sum_{i=0}^{q 2} \beta_{3 i} \Delta\left(\ln G D P^{2}\right)_{t-i}+\sum_{i=0}^{q 3} \beta_{4 i} \Delta(\ln T A)_{t-i}+\sum_{i=0}^{q 4} \beta_{5 i} \Delta\left(\ln T A^{2}\right)_{t-i}+ \\
& \sum_{i=0}^{q 5} \beta_{6 i} \Delta(\ln E U)_{t-i}+\varepsilon_{t}
\end{aligned}
$$

ARDL bound test hypotheses are established as follows:

$$
\begin{array}{lll}
\mathrm{H} 0: & \delta_{1}=\delta_{2}=\delta_{3}=\delta_{4}=\delta_{5}=\delta_{6}=0 & \text { (no cointegration) } \\
\mathrm{H} 1: & \delta_{1} \neq \delta_{2} \neq \delta_{3} \neq \delta_{4} \neq \delta_{5} \neq \delta_{6} \neq 0 & \text { (cointegration) }
\end{array}
$$

Where $\Delta$ represents the first difference operatör; $\alpha$ is the constant term; and $\delta_{1}, . \delta_{6}$ are the long-run coefficients; $\beta_{1}, \ldots \beta_{6}$, represent the short-run coefficients; $p, q_{1}, \ldots q_{5}$ are optimal lag orders; $\varepsilon_{t}$ represents the white noise error term.

The null hypothesis indicating that there is no cointegration among the variables is rejected when the calculated F statistic value is higher than the upper critical limit value (Pesaran et al. 2001. This result shows that there is a long-run relationship between variables. In case H0 is rejected, the next step is to estimate the Error Correction Model (ECM). At this stage, error testing is defined as follows to obtain short and long term dynamics: 


$$
\begin{aligned}
\Delta \operatorname{lnCO} 2_{t}=\alpha & +\sum_{i=1}^{p} \beta_{1 i} \Delta(\operatorname{lnCO2})_{t-i} \sum_{i=1}^{q 1} \beta_{2 i} \Delta(\ln G D P)_{t-i}+\sum_{i=1}^{q 2} \beta_{3 i} \Delta \ln G P_{t-i}^{2} \\
& +\sum_{i=1}^{q 3} \beta_{4 i} \Delta(\ln T A)_{t-i}+\sum_{i=1}^{q 4} \beta_{5 i} \Delta \ln T A_{t-i}^{2}+\sum_{i=1}^{q 5} \beta_{6 i} \Delta(\ln E U)_{t-i}+\lambda E C T_{t-1}+\varepsilon_{t}
\end{aligned}
$$

The coefficient $(\lambda)$ of the Error Correction Term $\left(\mathrm{ECT}_{\mathrm{t}-1)}\right.$ is expected to be negative and statistically significant. It shows how long it will take for short-term shocks caused by independent variables to disappear and approach the long-term equilibrium value. $\beta_{1}, \ldots, \beta_{6}$ are the short-run dynamic coefficients of the model.

The long-run, as well as short-run results of income, income squared, tourist arrival, energy consumption on $\mathrm{CO} 2$, are reported in Table 5. Calculated F statistics (4.90608) is greater than the upper critical value (3.79) at a 5\% level of significance. That is why the null hypothesis of no cointegration among variables are rejected. This confirms the presence of a long-run relationship among the variables.

\begin{tabular}{|c|c|c|c|c|}
\hline \multicolumn{5}{|c|}{ Panel A: F Bound Test } \\
\hline \multirow{2}{*}{$\begin{array}{l}\text { Model: ARDL }(4,1 \text {, } \\
0,0,0,0) \\
\text { Case 3: Unrestricted } \\
\text { Constant and No } \\
\text { Trend }\end{array}$} & $\begin{array}{c}\text { F-Bounds Test } \\
\text { Statistics }\end{array}$ & Significance & $\mathbf{I}(\mathbf{0})$ & $\mathbf{I}(\mathbf{1})$ \\
\hline & 4.90608 & $\begin{array}{c}\% 10 \\
\% 5 \\
\% 1\end{array}$ & $\begin{array}{l}2.26 \\
2.62 \\
3.41\end{array}$ & $\begin{array}{l}3.35 \\
3.79 \\
4.68\end{array}$ \\
\hline \multicolumn{5}{|c|}{ Panel B: Long-run elasticities Dependent Variable: $\operatorname{lnCO}_{2}$} \\
\hline Variable & Coefficient & Std. Error & t-Statistic & Prob. \\
\hline LNGDP & -0.011859 & 3.182400 & -0.003726 & 0.9970 \\
\hline LNGDP2 & 0.014814 & 0.170866 & 0.086697 & 0.9313 \\
\hline LNTA & 0.708563 & 0.279976 & 2.530798 & 0.0153 \\
\hline LNTA2 & -0.023050 & 0.009038 & -2.550330 & 0.0146 \\
\hline LNEU & 0.935011 & 0.224230 & 4.169877 & 0.0002 \\
\hline \multicolumn{5}{|c|}{$\mathrm{EC}=\mathrm{LNCO} 2-(-0.0119 *$ LNGDP $+0.0148 *$ LNGDP2 $+0.7086 *$ LNTA $-0.0231 *$ LNTA2 $+0.9350 *$ LNEU $)$} \\
\hline \multicolumn{5}{|c|}{ Panel C: Short-run elasticities and Error Correction Term } \\
\hline Variable & Coefficient & Std. Error & t-Statistic & Prob. \\
\hline $\mathrm{C}$ & -6.249239 & 1.088574 & -5.740758 & 0.0000 \\
\hline $\mathrm{D}(\mathrm{LNCO} 2(-1))$ & -0.097670 & 0.056718 & -1.722035 & 0.0926 \\
\hline $\mathrm{D}(\mathrm{LNCO} 2(-2))$ & 0.034747 & 0.053888 & 0.644807 & 0.5226 \\
\hline $\mathrm{D}(\mathrm{LNCO} 2(-3))$ & -0.111973 & 0.052741 & -2.123051 & 0.0398 \\
\hline $\mathrm{D}(\mathrm{LNEU})$ & 1.037990 & 0.072903 & 14.23805 & 0.0000 \\
\hline CointEq(-1)* & -0.523960 & 0.091173 & -5.746856 & 0.0000 \\
\hline \multicolumn{5}{|c|}{ Panel D: Diagnostic Test Statistics } \\
\hline \multicolumn{5}{|c|}{$\begin{array}{l}\text { Adjusted R-squared: } 0.8463 \\
\text { Durbin-Watson stat: } 1.9332\end{array}$} \\
\hline \multirow{2}{*}{\multicolumn{3}{|c|}{ Heteroskedasticity Test: Breusch-Pagan-Godfrey }} & Test istatistiği & Prob. \\
\hline & & & 7.9096 & 0.6377 \\
\hline
\end{tabular}

Table 5. Estimated Coefficients from ARDL Model 


\begin{tabular}{|l|l|l|}
\hline Breusch-Godfrey Serial Correlation LM Test & 0.2901 & 0.8649 \\
\hline Jarque-Bera Normality Test & 0.8774 & 0.6448 \\
\hline Ramsey RESET Test & 0.2879 & 0.5945 \\
\hline
\end{tabular}

Table 5 reports the results for short and long-run estimates for the model with $\mathrm{CO} 2$ emissions as the dependent variable and economic growth, international tourist arrival and energy usage as independent variables. The coefficients $\beta 1<0$ and $\beta 2>0$ are not statistically significant and do not confirm the existence of the EKC hypothesis between economic growth and environmental degradation. This finding is not similar to the majority of studies, such as in Zaman et al. (2016), Solarin (2014), Al-Mulali et al. (2015), Shahbaz et al. (2015), Lee and Brahmasrene (2013), Katircioğlu (2014) and Ben Jebli et al. (2019) and consistent with Tiwari et al. (2013). Some studies find an N-shape relationship between the variables (Destek et al. 2020).

On the other hand, the results $(\beta 3>0$ and $\beta 4<0)$ support the hypothesis that increasing tourism demand increases environmental pollution up to a point where the sector attains a certain development level, after which emissions begin to fall. These results confirm an inverted U-shaped relationship between international tourist arrival and CO2 emissions. The result is consistent with Katircioğlu (2014b), Sherafatian-Jahromi et al. (2017), BalsalobreLorente et al. (2002), Shakouri et al. (2017) and Paramati et al. (2016).

The analysis results also show that energy usage (EU) has a positive and significant impact on CO2 in the long run. A $1 \%$ increase in EU increases $\mathrm{CO} 2$ emissions by $0.935 \%$. An increase in income, tourism, transportation and communication increases the demand for energy sources which production depends on mainly fossil fuels such as gas, oil and coal which produce $\mathrm{CO} 2$ and other GHG emissions. The result consistents with Khan et al. (2020), Say\&Yücel (2006), Katırcıgle et al. (2014) and Doğan\&Aslan (2017), Al-Mulali\&Sheau-Ting (2014).

The analysis results also show that there is a short-run relationship between $\mathrm{CO} 2$ and energy usage as shown in Panel $\mathrm{C}$ of Table 5. This result confirms that the most important source of $\mathrm{CO} 2$ emissions is energy usage in the long run and short run. As can be seen in Table 5, the coefficient of the error correction term ECT $\mathrm{T}_{\mathrm{t}-1}(-0.523)$ is negative and statistically significant confirming a long-run relationship between $\mathrm{CO} 2$ emissions, tourist arrival, income growth and energy usage. In addition, the error correction term states that $52,3 \%$ of an imbalance that occurs in the short run will disappear in the first year. In other words, an imbalance in the short term will come back to long-term equilibrium approximately in 2 years $(1 / 0,523)$.

The results of diagnostic tests for the error-correction model, i.e. serial correlation test, functional form specification, normality test and heteroscedasticity test are reported in Panel D of Table 5. The test results accept null hypotheses stating that there is no econometric problem in the model.The estimated model also passes the diagnostic tests of normality and functional form. The diagnostic test results suggest that the estimated model is stable over the sample period. The high R-squared is indicative of the good explanatory power of the model. To check the stability of the short-and long-run estimates, CUSUM and CUSUM of squares are also employed. Figure 1 and Figure 2 show CUSUM and CUSUM of squares where CO2 is the dependent variable. The plots of both statistics are well within the critical 5\% bounds that confirm the stability of coefficients in the error-correction model.

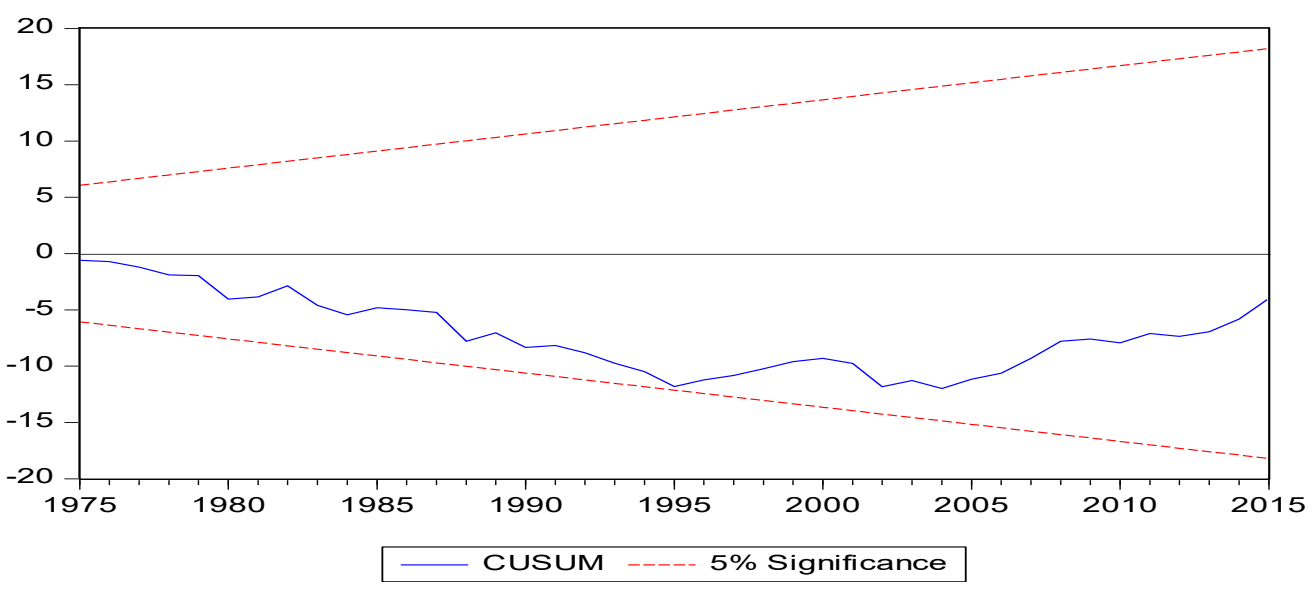

Figure 1. Plot of Cumulative Sum of Recursive Residuals 


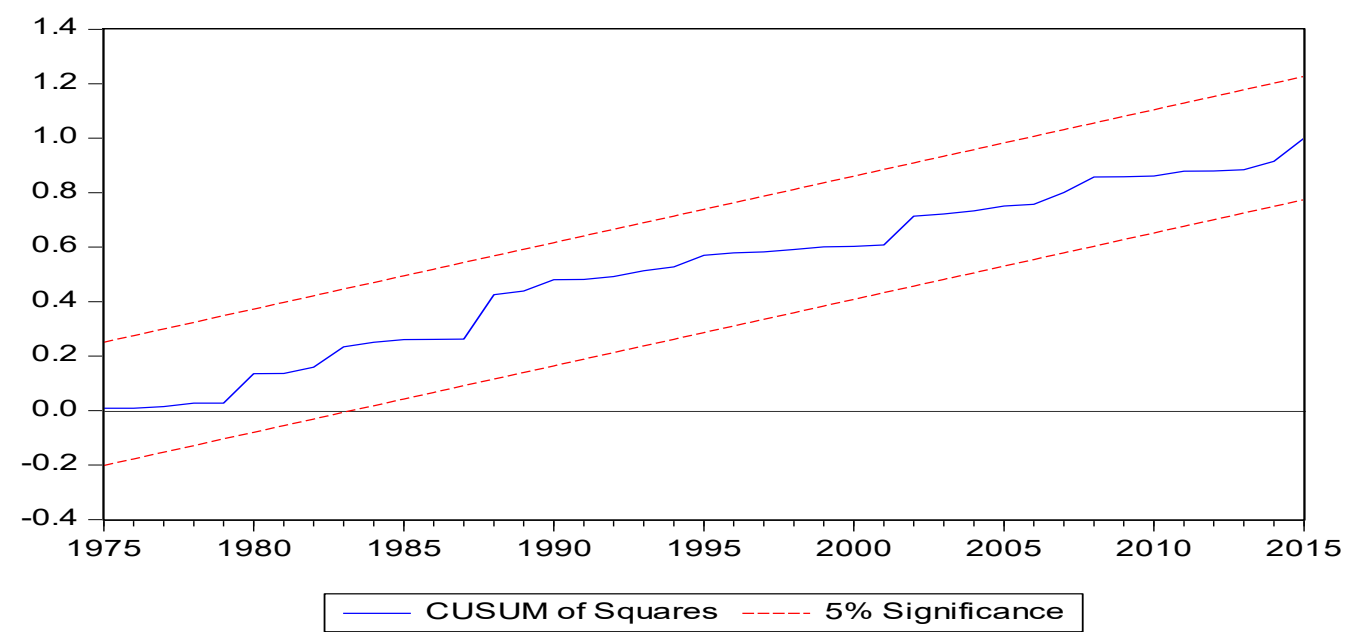

Figure 2. Plot of Cumulative Sum of Squares of Recursive Residuals.

\section{DISCUSSION AND CONCLUSION}

This paper examined the presence of a long-run relationship among $\mathrm{CO} 2$ emissions, tourist arrival, economic growth, and energy consumption in Turkey. ARDL Bound test results show the existence of a long-run relationship among the variables. These results confirm an inverted U-shaped relationship between international tourist arrival and CO2 emissions. The results are in line with Katircioğlu (2014b), Sherafatian-Jahromi et al. (2017), Balsalobre-Lorente et al. (2002), Shakouri et al. (2017) and Paramati et al. (2016). The tourism sector is an energy-intensive sector in many areas such as accommodation, heating/cooling, transportation and more tourist arrivals creates more demand for energy which translates to significant emissions. This finding supports the idea which more tourist arrivals create more demand for energy which translates to significant emissions. Then the analysis results of this paper confirm that energy use leads to increase $\mathrm{CO} 2$ emissions. Our analysis results do not provide any evidence for the EKC hypothesis between economic growth and $\mathrm{CO} 2$ emissions in Turkey during the period under study. This result is not similar to findings of Zaman et al. (2016), Solarin (2014), Al-Mulali et al. (2015), Shahbaz et al. (2015), Lee and Brahmasrene (2013), Katircioğlu (2014) and Ben Jebli et al. (2019) and consistent with Tiwari et al. (2013).

The tourism sector is an important sector for Turkey in terms of both income and employment. In 2019, the share of the tourism and travel sector in Turkey's GDP is $11.3 \%$. On the other hand, the number of people working in the tourism sector in Turkey is about 2.6438 million people, and this figure is equivalent to $9.4 \%$ of total employment (TÜİK, 2020). The sector was following a positive trend before the pandemic and had 51,9 $\mathrm{mn}$ visitors and US\$34,5 bn total receipts in 2019 (EY Turkey, 2020). Tourism is an energy-dependent sector that causes a significant positive impact on environmental pollution in Turkey. For sustainable development, all sectors including tourism must improve infrastructure construction, enhance environmental awareness, investment in renewable energy services and focus on eco-friendly policies to reduce carbon emissions and environmental pollutions. This is also important to protect the environment and increase Turkey's competitiveness in the world. Energy, which causes industrial revolutions and a more comfortable life, has turned into a problem that threatens human life, such as climate changes and environmental pollution It has vital importance for the whole world to support investments in clean energy and low-carbon technologies for sustainable development and sustainable tourism. These investments could avert the worst warming and reduce the negative effects of climate changes on tourism in the world. The subject of the next study will be to investigate the effects of the decrease in tourism demand due to global climate changes on employment, income and migration in tourismdependent countries. Especially, international migration which is a big problem for Turkey and unemployment are going to the most important problems in the future in the world. Therefore, to prevent environmental pollution and prevent global warming, increasing international joint efforts, especially in the field of energy, should be considered as an emergency for sustainable development and a peaceful world. 


\section{REFERENCES}

AL-MULALI U. \& SHEAU-TING, L. (2014). "Econometric analysis of trade, exports, imports, energy sonsumption and CO2 emission in six regions", Renewable and Sustainable Energy Reviews, Vol. 33, 484498.

AL-MULALI, U., OZTURK, I., \& LEAN, H. H. (2015). "The Influence of Economic Growth, Urbanization, Trade Openness, Financial Development, and Renewable Energy on Pollution in Europe". Nat Hazards 79: 621-644. DOI: 10.1007/s11069-015-1865-9.

AZAM, M., ALAM, M., M. \& HAFEEZ, M. H. (2018). "Effect of Tourism on Environmental Pollution: Further Evidence from Malaysia, Singapore and Thailand". Journal of Cleaner Production. 190, 330-338. https://doi.org/10.1016/j.jclepro.2018.04.168.

BALLI, E., CILER SIGEZE, C., MANGA, M., BIRDIR, S., \& BIRDIR, K. (2019). "The Relationship Between Tourism, CO2 Emissions and Economic Growth: A Case of Mediterranean Countries". Asia Pacific Journal of Tourism Research, 24:3, 219-232, DOI: 10.1080/10941665.2018.1557717.

BALSALOBRE-LORENTE, D., DRIHA, O. M., SHAHBAZ, M., \& SINHA, A. (2020). "The Effects of Tourism and Globalization Over Environmental Degradation in Developed Countries". Environmental Science and Pollution Research, 27, 7130-7144. https://doi.org/10.1007/s11356-019-07372-4.

BECKEN, S.\& SIMMONS, D.G. (2002). "Understanding energy consumption patterns of tourist attractions and activities in New Zeland”, Tourism Management, 23, 343-354.

BEN JEBLI, M., BEN YOUSSEF, S., \& APERGIS, N. (2015). "The Dynamic Interaction Between Combustible Renewables and Waste Consumption and International Tourism: The Case of Tunisia". Environ Sci Pollut Res Int, 22(16): 12050-61. Doi: 10.1007/s11356-015-4483-x.

BEN JEBLI, M., BEN YOUSSEF, S., \& APERGIS, N. (2019). "The Dynamic Linkage Between Renewable Energy, Tourism, CO2 Emissions, Economic Growth, Foreign Direct Investment, and Trade". Latin American Economic Review 28, 2(2019). https://doi.org/10.1186/s40503-019-0063-7.

CHISHTI, M. Z., ULLAH, S., \& OZTURK, I.\&USMAN, Al. (2020). "Examining The Asymmetric Effects of Globalization and Tourism on Pollution Emissions in South Asia”. Environ Sci Pollut Res 27, 27721-27737 https://doi.org/10.1007/s11356-020-09057-9.

CHURKINA, G. (2016). "The Role of Urbanization in the Global Carbon Cycle". Frontiers in Ecology and Evolution, https://doi.org/10.3389/fevo.2015.00144 .

CRIPPA, M., GUIZZARDI, D., MUNTEAN, M., SCHAAF, E., SOLAZZO, E., MONFORTI-FERRARIO, F., OLIVIER, J. G. J., \& VIGNATI, E. (2020). Fossil CO2 Emissions of All World Countries- 2020 Report. Publications Office of the European Union, Luxembourg.

DESTEK, M. A., SHAHBAZ, M., OKUMUS, I. et al. (2020). "The Relationship Between Economic Growth and Carbon Emissions in G-7 Countries: Evidence From Time-Varying Parameters With A Long History". Environ Sci Pollut Res 27, 29100-29117. https://doi.org/10.1007/s11356-020-09189-y.

DOĞAN, E., \& ASLAN, A. (2017). "Exploring The Relationship Among CO2 Emissions, Real GDP, Energy Consumption and Tourism in The EU and Candidate Countries: Evidence From Panel Models Robust to Heterogeneity and Cross-Sectional Dependence". Renewable \& Sustaınable Energy Reviews, Vol.77, 239-245.

DOĞAN, E., SEKER, F., \& BULBUL, S. (2017). "Investigating The Impacts of Energy Consumption, Real GDP, Tourism and Trade on CO2 Emissions by Accounting for Cross-Sectional Dependence: A Panel Study of OECD Countries". Curr Issues Tour 20:1701-1719.

DURBARRY, R., \& SEETANAH, B. (2015). "The Impact of Long Haul Destinations on Carbon Emissions: The Case of Mauritius". Journal of Hospitality Marketing \& Management, 24:4, 401-410, DOI: 10.1080/19368623.2014.914363.

DWYER, L., FORSYTH, P., SPURR, R., \& HOQUE, S. (2010). "Estimating The Carbon Footprint of Australian Tourism". Journal of Sustainable Tourism, 18(3), 355-376.

ELLIOT, G., T.J. ROTHENBERG and J.H. STOCK, (1996). "Efficient tests for an autoregressive unit root". Econometrica, 64(4): 813-836. 
KILAVUZ, Emine, ORALHAN, Burcu, SUMERLI SARIGUL, Sevgi and ULUG, Eyup Emre- The Validity of the Tourism-induced EKC Hypothesis: The Case of Turkey

ENGLE, ROBERT F., \& GRANGER, C. W. J. (1987). "Con-Integration and Error Correction: Representation, Estimation and Testing”. Econometrica, Vol. 55, Issue 2, 251-276.

EPA, Global Greenhouse Gas Emissions Data Available at: https://www.epa.gov/ghgemissions/globalgreenhouse-gas-emissions-data, Accessed 2019 Sep. 11.

EY Turkey. (2020). Tourism Market Overview. Ernst Young Kurumsal Finansal Danışmanlık AŞ (EY Turkey), 1-34.

FANG, Y., YIN, J., \& WU, B. (2018). "Climate Change and Tourism: A Scientometric Analysis Using Citespace". Journal of Sustainable Tourism, 26:1, 108-126.

FORSTER, P. M., FORSTER, H. I., \& EVANS, M. J. et al. (2020). "Current and Future Global Climate Impacts Resulting from COVID-19”. Nat. Clim. Chang. 10, 913-919 https://doi.org/10.1038/s41558-020-0883-0 .

GÖSSLING, S. (2013). “National emissions from tourism: An overlooked policy challenge?” Energy Policy Vol. $59,433-442$.

GÖSSLING, S., SCOTT, D., \& HALL, C.M. (2020). "Pandemics, Tourism and Global Change: A Rapid Assessment of COVID-19”. Journal of Sustainable Tourism, 29:1, 1-20.

GROSSMAN, G. M., \& KRUEGER, A. B. (1991). "Environmental Impacts of A North American Free Trade Agreement". NBER Working Paper No. 3914.

GROSSMAN, G. M., \& KRUEGER, A. B. (1995). "Economic Growth and The Environment". The Quarterly Journal of Economics", 110(2), 353-378. https://doi.org/10.2307/2118443.

HANSEN, B. E., \& PHILLIPS P. C. B. (1990). "Estimation and Inference in Models of Cointegration: A Simulation Study". Advances in Econometrics, Vol. 8, 225-248.

HOOGENDOORN, G., \& FITCHETT, J. M. (2016). "Tourism and Climate Change: A Review of Threats and Adaptation Strategies for Africa", Current Issues in Tourism, 21(7), 742-759.

HØYER, K. G. (2000). "Sustainable Tourism or Sustainable Mobility? The Norwegian Case". Journal of Sustainable Tourism, 8:2, 147-160, DOI: 10.1080/09669580008667354.

IŞIK, C., EVANGELIA K., \& ONGAN S. (2017). "Analyzing the Causalities Between Economic Growth, Financial Development, International Trade, Tourism Expenditure and/on The CO2 Emissions in Greece". Energy Sources, Part B: Economics, Planning, and Policy, 12:7, 665-673, DOI: 10.1080/15567249.2016.1263251.

JOHANSEN, S., (1988). "Statistical Analysis Of Cointegration Vectors". Journal of Economic Dynamics and Control, Vol. 12, 231-254.

KATIRCIOĞLU, S. T. (2014a). "International Tourism, Energy Consumption, and Environmental Pollution: The Case of Turkey". Renewable and Sustainable Energy Reviews, Elsevier, Vol. 36(C), pages 180-187. DOI: 10.1016/j.rser.2014.04.058

KATIRCIOĞLU, S. T., FERIDUN, M., \& KILINC, C. (2014). "Estimating Tourism-Induced Energy Consumption and CO2 Emissions: The Case of Cyprus", Renewable and Sustainable Energy Reviews 29, 634640.

KATIRCIOĞLU, S.T. (August 2014b). "Testing the tourism-induced EKC hypothesis: The case of Singapore", Economic Modelling, Vol: 41, 383-391

KELLY, J., \& WILLIAMS, P. W. (2007). "Modelling Tourism Destination Energy Consumption and Greenhouse Gas Emissions: Whistler, British Columbia”, Canada. Journal of Sustainable Tourism, 15:1, 67-90, DOI: 10.2167/jost609.0.

KHAN, A., BIBI, S., ARDITO, L., LYU, J., HAYAt, H., \& ARIF A. M. (2020). "Revisiting The Dynamics of Tourism, Economic Growth, and Environmental Pollutants in The Emerging Economies"-Sustainable Tourism Policy Implications. Sustainability, 1-23.

KOÇAK, E., ULUCAK, R., ULUCAK Z. Ş. (2020). "The Impact of Tourism Developments on CO2 Emissions: An Advanced Panel Data Estimation”. Tour Manag Perspect 33:100611. 
LEE, W. L., \& BRAHMASRENE, T. (2013). "Investigating The Influence of Tourism on Economic Growth and Carbon Emissions: Evidence from Panel Analysis of The European Union". Tourism Management, Elsevier, vol. 38(C), 69-76.

LENZEN, M., YA YEN S., FUTU F., YUAN P. T., ARNE, G., \& ARUNIMA M. (2018). “The Carbon Footprint of Global Tourism". Nature Climate Change 8 (6): 522-28.

Liu, J., Feng, T., \& Yang, X. (2011). The Energy Requirements and Carbon Dioxide Emissions of Tourism Industry of Western China: A Case of Chengdu City. Renewable\& Sustainable Energy Reviews, 15, 2887-2894.

LIU, Z., CIAIS, P., \& DENG, Z. et al. (2020). "Near-Real-Time Monitoring of Global CO2 Emissions Reveals The Effects of The COVID-19 Pandemic". Nature Communications 11, 5172. https://doi.org/10.1038/s41467020-18922-7.

NEPAL, R., AL IRSYAD, M. I., \& NEPAL, S. K. (2019). "Tourist Arrivals, Energy Consumption and Pollutant Emissions in A Developing Economy-Implications for Sustainable Tourism”, Tourism Management, 72, 145154. https://doi.org/10.1016/j.tourman.2018.08.025 .

NEPAL, S. K. (2008). "Tourism-Induced Rural Energy Consumption in The Annapurna Region of Nepal", Tourism Management, 29, 89-100.

PANDY, W. R. (2017). "Tourism Enterprises and Climate Change: Some Research Imperatives". African Journal of Hospitality Tourism and Leisure, Volume 6 (4), 1-18.

PANWAR, N. L., KAUSHIK, S. C., \& KOTHARI, S. (2011). "Role of Renewable Energy Sources in Environmental Protection: A Review". Renewable and Sustainable Energy Reviews 15: 1513-1524. doi:10.1016/j.rser.2010.11.037

PARAMATI, S. R., ALAM S., \& CHEN, C. F. (2016). "The Effects of Tourism on Economic Growth and CO2 Emissions: A Comparison between Developed and Developing Economies". Journal of Travel Research, 1-13.

PESARAN, M. H., SHIN, Y., \& SMITH R. P. (1999). "Pooled Mean Group Estimation of Dynamics Heterogeneous Panels". Journal of the American Statistical Association, Vol. 94, Issue 446, , 621-634.

PESARAN, M. H., SHIN, Y., \& SMITH, R. J. (2001). "Bounds Testing Approaches to The Analysis of Level Relationships”. Journal of Applied Econometrics, Vol. 16, 289-326.

SAENZ-DE-MIERA O., \& ROSSELLÓ, J. (2014). "Modeling Tourism Impacts on Air Pollution: The Case Study of PM10 in Mallorca”. Tourism Management, Vol. 40, 273-281.

SAJJAD, F., NOREEN, U., \& ZAMAN, K. (2014). "Climate Change and Air Pollution Jointly Creating Nightmare for Tourism Industry”. Environmental Sciences and Pollution Research, 21(21), 12403-12418.

SALAHUDDIN, M., ALI, M. I., \& VINK, N. et al. (2019). "The Effects of Urbanization and Globalization on CO2 Emissions: Evidence from The Sub-Saharan Africa (SSA) Countries”. Environ Sci Pollut Res 26, 26992709 (2019). https://doi.org/10.1007/s11356-018-3790-4 .

SAY, N.P.\& YÜCEL, M. (2006). "Energy consumption and CO2 emissions in Turkey: Emprical analysis and future projection based on an economic growth", Energy Policy, 34, 3870-3876.

SCOTT, D. (2011). "Why Sustainable Tourism Must Address Climate Change". Journal of Sustainable Tourism, 19:1, 17-34, DOI: 10.1080/09669582.2010.539694

SCOTT, D., \& LEMIEUX, C. (2010). "Weather and Climate Information for Tourism", Procedia Environmental Sciences, Vol. 1, 146-183.

SERRANO-BERNARDO, F. A., ROSUA-CAMPOS, J. L., BRUZZI, L., \& TOSCANO, E. H. (2012). “Air Pollution-A Comprehensive Perspective". Edited by Budi Haryanto, DOI: 10.5772/50418.

SHAHBAZ, M., LOGANATHAN, N., MUZAFFAR, A.T., AHMED, K., \& JABRAN, M. A. (2015). "How Urbanization Affects CO2 Emissions in Malaysia? The Application of STIRPAT Model". MPRA Paper No. 68422 .

SHAKOURI, B., KHOSHNEVIS, S., \& GHORCHEBIGI, E. (2017). "Does Tourism Development Promote CO2 Emissions?" Anatolia An International Journal of Tourism and Hospitality Research, 28(3), 444-452. 
SHERAFATIAN-JAHROMI, R., OTHMAN, M. S., LAW, S. H., \&ISMAIL, N. W. (2017). "Tourism and CO2 Emissions Nexus Southeast Asia: New Evidence from Panel Estimation". Environment, Development and Sustainability, 19, 1407-1432.

SOLARIN, S. A. (2014). "Tourist Arrivals and Macroeconomic Determinants of CO2 Emissions in Malaysia". Anatolia: An International Journal of Tourism and Hospitality Research, 25:2, 228-241.

STATISTA, (2020). https://www.statista.com/statistics/449827/co2-emissions-turkey/. Accesed by 09.15.2020.

TANG, Z., BAI, S., SHI, C., LIU, L., \& LI, X. (2018). “Tourism-Related CO2 Emission and Its Decoupling Effects in China: A Spatiotemporal Perspective". Advances in Meteorology, Vol. 2018, 1-9.

THE WORLD BANK, Available at: http://data.worldbank.org/indicator/EG.USE.CRNW.ZS

TIWARI, A. K., OZTURK, I., \& ARUNA, M. (2013). "Tourism, Energy Consumption and Climate Change in OECD Countries”. International Journal of Energy Economics and Policy, 3(3) 247-261.

TÜRKIYE İSTATISTIK KURUMU (TUIK), Available at: http://www.tuik.gov.tr/PreTablo.do?alt_id=1072

UNGER, R., ABEGG, B., MAILER, M., \& Stampfl, P. (2016). "Energy Consumption and Greenhouse Gas Emissions Resulting From Tourism Travel in an Alpine Setting". Mountain Research and Development, 36(4), 475-483.

UNWTO (7 May 2020). International Tourist Numbers Could Fall 60-80\% in 2020, UNWTO Reports, Available at: https://www.unwto.org/news/covid-19-international-tourist-numbers-could-fall-60-80-in-2020 .

UNWTO, UNEP, WMO (2008). Climate Change and Tourism: Responding to Global Challenges, United Nations World Tourism Organization (UNWTO), United Nations Environment Programme (UNEP) and World Meteorological Organization (WMO), UNWTO, Madrid, 1-237.

WEAVER, D., (2011). “Can Sustainable Tourism Survive Climate Change?” Journal of Sustainable Tourism, 19:1, 5-15.

WORLD ECONOMIC FORUM (WEFORUM), (07 Jun 2019). Chart of The Day: These Countries Create Most of The World's CO2 Emissions, Available at: https://www.weforum.org/agenda/2019/06/chart-of-the-day-thesecountries-create-most-of-the-world-s-co2-emissions/.

WORLD TOURISM ORGANIZATION (UNWTO) and International Transport Forum (ITF) (December 2019). Transport-Related CO2 Emissions of the Tourism Sector - Modelling Results, UNWTO, Madrid, Spain, 1-68.

WORLD TOURISM ORGANIZATION (UNWTO) and United Nations Environment Programme (UNEP) (2008). Climate Change and Tourism - Responding to Global Challenges, UNWTO, Madrid, Spain, 1-269.

WU, P., \& SHI, P. (2011). "A Rough Estimation of Energy Consumption and CO2 Emission in Tourism Sector of China”. Journal of Geographical Sciences, 21(4), 733-745.

YAZDI S. K., \& DARIANI A. G. (2019). “CO2 Emissions, Urbanisation and Economic Growth: Evidence from Asian Countries”, Economic Research-Ekonomska Istraživanja, 32:1, 510- $530 . \quad$ DOI: 10.1080/1331677X.2018.1556107 .

ZAMAN, K., SHAHBAZ, M., LOGANATHAN, N.\& RAZA, S.A. (2016). "Tourism development, energy consumption and Environmental Kuznets Curve: Trivariate analysis in the panel of developed and developing countries”, Tourism Management, 54, 275-283. 